\title{
"The effect of Lerner Index and income diversification on the general bank stability in Indonesia"
}

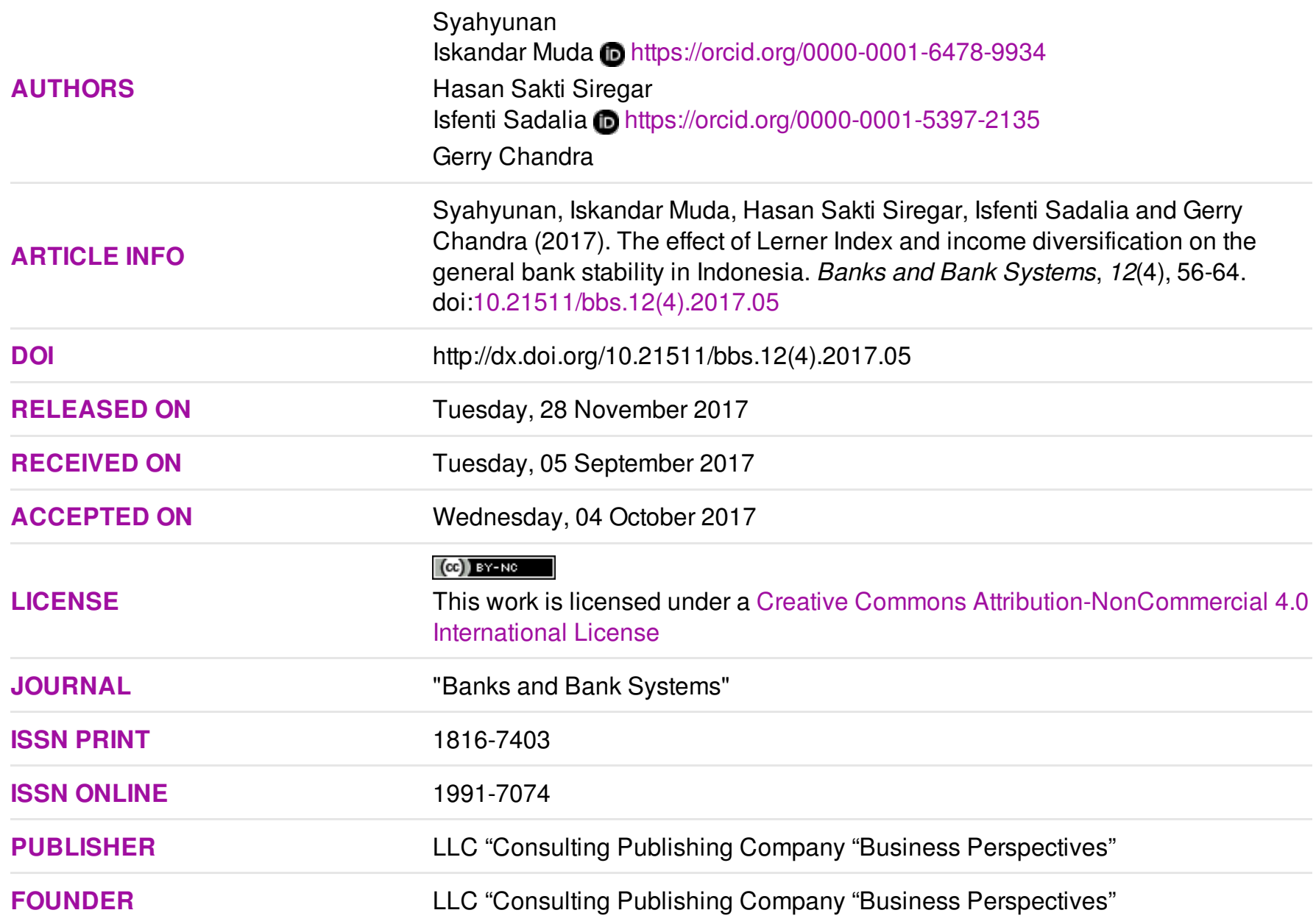

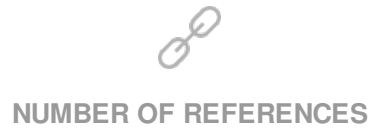

49

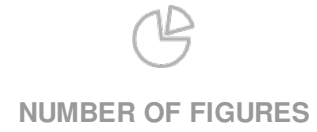

1
NUMBER OF TABLES

4

(C) The author(s) 2022. This publication is an open access article. 


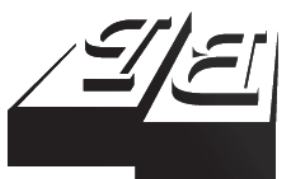

BUSINESS PERSPECTIVES

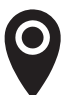

LLC "CPC "Business Perspectives" Hryhorii Skovoroda lane, 10, Sumy, 40022, Ukraine

www.businessperspectives.org

Received on: $5^{\text {th }}$ of September, 2017 Accepted on: $4^{\text {th }}$ of October, 2017

C) Syahyunan, Iskandar Muda, Hasan Sakti Siregar, Isfenti Sadalia, Gerry Chandra, 2017

Syahyunan, Dr., Management Department, Faculty of Economics and Business, Universitas Sumatera Utara, Medan, Indonesia.

Iskandar Muda, Dr., Accounting Department, Faculty of Economics and Business, Universitas Sumatera Utara, Medan, Indonesia.

Hasan Sakti Siregar, Dr., Accounting Department, Faculty of Economics and Business, Universitas Sumatera Utara, Medan, Indonesia.

Isfenti Sadalia, Dr., Management Department, Faculty of Economics and Business, Universitas Sumatera Utara, Medan, Indonesia.

Gerry Chandra, Management Department, Faculty of Economics and Business, Universitas Sumatera Utara, Medan, Indonesia.

\section{(ㄷ)(1) $(9$}

This is an Open Access article, distributed under the terms of the Creative Commons Attribution-NonCommercial 4.0 International license, which permits re-use, distribution, and reproduction, provided the materials aren't used for commercial purposes and the original work is properly cited.
Syahyunan (Indonesia), Iskandar Muda (Indonesia),

Hasan Sakti Siregar (Indonesia), Isfenti Sadalia (Indonesia),

Gerry Chandra (Indonesia)

\section{THE EFFECT OF LERNER INDEX AND INCOME DIVERSIFICATION ON THE GENERAL BANK STABILITY IN INDONESIA}

\begin{abstract}
The purpose of this study is to examine the effect of market power and income diversification on the General Bank stability in Indonesia. This research uses a data sample of 20 general banks listed on the Indonesia Stock Exchange for the period of 2011-2014. Data analysis technique used is Multiple Linear Regression. It can be concluded simultaneously that market power and revenue diversification have significant effect on bank stability and, partially, market power has a positive and significant effect on a bank stability. Income diversification has a positive non-significant effect on bank stability.
\end{abstract}

\section{Keywords market power, revenue diversification, bank stability, Indonesia Stock Exchange}

\section{JEL Classification G21, M12, L84}

\section{INTRODUCTION}

Basically, banking sector is the internal part of financial system. In Indonesia, financial system is still focusing on banking sector which has a crucial role in the financing activity of the real sector. Banking industry is one of the most important components of the country's economy. Generally, the stability of banking system is reflected by banking's health condition and the proceeding of banking intermediation function in mobilizing society' saving to distribute in the form of credit or another form of financing for the business world (Warjiyo, 2006; Khaldun \& Muda, 2014). The stability of a country's financial system must be maintained in order to avoid an economic crisis that affects the stability of the country as a whole, as well as its security and welfare. The economic crisis that once hit Indonesia in 1997-1998 became an example of seeing how the devastating are effects of financial system instability. Similar to family finances, the stability of the country's financial system is influenced by many factors, including internal factors such as the performance of the banking sector with liquidity risk, credit risk and market risk, non-bank financial institutions, financial markets and financial infrastructure, and influenced by external factors that are world economic factors. In addition to economic factors, the stability of the financial system is strongly influenced by non-economic factors, namely the political situation and security of the country. Therefore, in order to maintain the financial system stability, state security, a conducive climate should be kept so investors feel safe to keep investing and can invite new investors to invest in Indonesia. 
The liquidity difficulties of a bank can be systemic, meaning it can correlate with other banking/ financial institutions or economic system in whole, which can result in mistrust of the banking community and will disrupt the financial system stability. The causes of the bank's general liquidity difficulties are the bank's failure to manage and supervise credit, failure to manage administration and operational costs, decreasing public interest in saving or investing in the bank as a result of the declining public trust with the bank's performance in managing the trust (Rini \& Absah, 2017). In this research, the stability of bank is proxied by Z-score as the measurement of bank stability. Some previous researches tried to determine the factors that affect bank's stability. The amount of bank's market power will impact the increase in bank stability. A bank with more efficient market power, sufficient resources, sufficient scale and economic scope can do low cost activities and enjoy high profit margin (Nurzaimah et al., 2016). Besides market power, income diversification can also affect bank's stability. Income diversification is one of the banking's efforts to increase bank's profitability (Mahdaleta et al., 2016; Lutfi et al., 2016). Research related to income diversification in the banking industry has been done in the USA and some European countries (Baele et al., 2007; Laeven \& Levine, 2007; Chiorazzo et al., 2008; Sanya \& Wolve, 2011; Brighi \& dan Venturelli, 2014), as well as Asia and Africa (Vennet, 2002; Acharya et al., 2006; Deng et al., 2007; Elyasiani \& Wang; 2012; Sawada, 2013; Zhou, 2014; Alhassan, 2015; Sianipar, 2015). Sianipar (2015) found that income diversification is capable of lowering non-systematic risks and total bank risks. Non-interest income sources able to lower risk is income fee. Diversification can reduce non-systematic risk, improve profitability and decrease cost inefficiency, but not significantly increase the market value of banks. In the world of banking, income diversification is considered to develop rapidly, because the technology advances ease the customers to do transaction (Muda et al., 2017). Besides, the technology advances can decrease the cost of financial transaction process and facilitate getting the information. The technology advances cause the increasing of non-interest income from bank's service. Based on the background, researches are interested in studying the effect of market power and income diversification on the commercial bank listed on the Indonesia Stock Exchange.

\section{LITERATURE REVIEW}

\subsection{Banking}

According to Act of Indonesia No. 10, 1998, banking is anything related to a bank, comprising instituions, business activities, and procedures as well as processes in such business activities conducting. Meanwhile, bank is a corporate entity that mobilizes funds from the public in the form of deposits and channels them to the public in the form of credit and/or other forms in order to improve the living standards of the society.

\subsection{Banking stability}

According to Crockett (1997), financial stability is related to two elements: monetary stability and financial stability. Monetary stability is price stabilility which refers to currency stability, whereas financial stability is a stability which refers to the financial institution stability. The stability between these two sectors must be controlled because both of them affect each other. If there is a disturbance between these two sectors, it will give negative effect on the economic growth (Tarmizi et al., 2016, 2017). For example, high inflation can cause the increase in interest rate and will lead to the increase in non-performing loans. The worse case is that it will spark the fall of banking and other financial institutions. Otherwise, if there is a disturbance in the banking stability, it will affect monetary system and disturb price stability. The indicator to measure banking stability is Z-score.

\subsection{Income diversification}

Bank's income diversification is bank's activities to gain income which are not only from the interest income but also non-interest income which comes from financial services served by bank to its customers such as credits, e-banking, trans- 
fer cost, trading, commission, and other services. Income diversification in banking sector can be seen as the increase in share of fee, net trading profit, and other non-interest income (Mahdaleta et al., 2016).

\subsection{Market power}

Market power is a company's capacity to sell its products at the price higher than its marginal cost (Kachtouli \& Hamza, 2014; Sirojuzilam et al., 2016). It can be concluded that the higher the market share is, the higher the market power will be. The ownership structure can affect bank performance because different types of ownership will give managers different incentives to efficiently allocate resources (Muda et al., 2017). In other words, the ownership structure can affect the technical efficiency of banking. Banking market share as measured by asset ownership is expected to have a positive effect on bank efficiency, because banks with larger market share tend to be more efficient than other banks. The greater asset owned by a bank is expected to further improve the efficiency of the bank, because banks with greater asset value tend to be able to pay lower input costs than their competitors and can increase the return to scale through fixed cost allocation. With the result that it can establish low interest rate for deposits and high interest rate for credit, and it will lead to higher profit. Market power is measured by Lerner index.

\subsection{Conceptual framework}

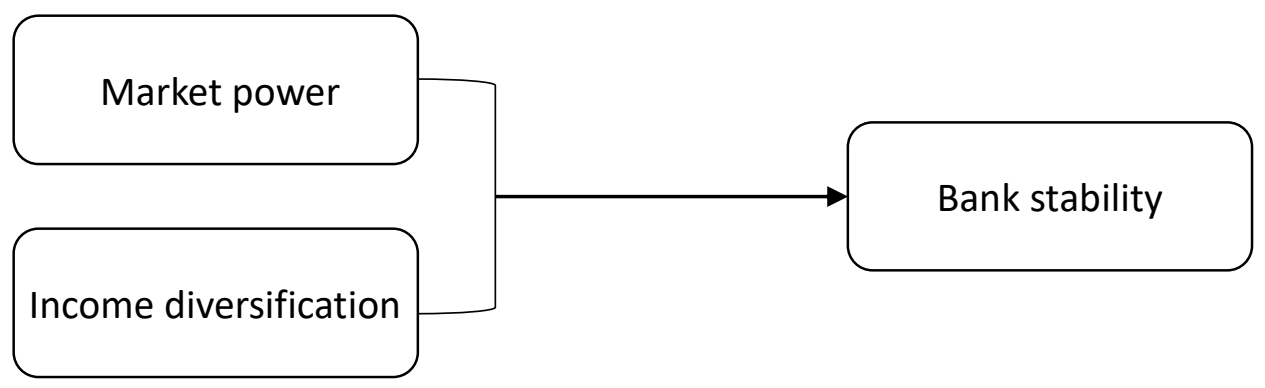

Figure 1. Conceptual framework

Based on the conceptual framework, the hypothes in this research is market power and income diversification affect the general bank's stability which is listed on the Indonesia Stock Exchange. This research aims to analyze the effect of market power and income diversification on the general bank's stability which is listed the Indonesia Stock Exchange.

\section{RESEARCH METHODS}

\subsection{Research design}

The research was undertaken using a quantitative explanatory approach with a causal ex post facto method, i.e. to determine the causal relationship between the research variables or survey explanatory which is a study decribing the relationship between several variables and other variables (Muda \& Rafiki, 2014; Maksum et al., 2014; Tarmizi et al., 2016, 2017). The research was undertaken using a quantitative explanatory approach with a causal method, i.e. to determine the causal relationship between the research variables. Therefore, based on the explanation or confirmation of describing the causal relationship and hypothesis testing (Lubis et al., 2016; Muda \& Dharsuky, 2015; Muda et al., 2016, 2017). The data analysis techniques used are: (i) descriptive statistical tests; (ii) classical assumptions test and hypothesis test with (a) F test (simultaneous); (b) $\mathrm{T}$ test (partial; (c) determination test, and (4) R2 test (coefficient of determination).

\section{Bank stability}


Table 1. Definitions and measurements of research variables

\begin{tabular}{|c|c|c|c|}
\hline No. & Variable & Indicator & Measuring scale \\
\hline 1 & Bank stability (Y) & $Z=\frac{R O A+\frac{E}{T A}}{\sigma_{R O A}}$ & Ratio \\
\hline 2 & Market power (X1) & Index Lerner $=\frac{P_{T A_{i t}}-M C_{T A_{i t}}}{P_{T A_{i t}}}$ & Ratio \\
\hline 3 & Income diversification (X2) & $N I I=\frac{\text { Net Non }- \text { Interest Income }}{\text { Net Operating Income }}$ & Ratio \\
\hline
\end{tabular}

\subsection{Research population and sample}

The population used in this research is all of the general banks which are listed on the Indonesia Stock Exchange during 2007-2014, which consists 40 companies. According to the criteria, there are 20 companies who become sample.

\subsection{Data analysis technique}

To process and analyze data, researchers use statistic program, SPSS for windows. The data analysis method in this research are descriptive statistic and multiple linear regression.

\section{RESULTS AND DISCUSSIONS}

\subsection{Descriptive analysis}

Descriptive statistic is statistic science which learns about the way to gather, to organize, and to serve a research data. The purpose is to ease people to read and to understand the data. This is the output of SPSS, which is the whole data used in this research.

Table 2 showed that the amount data used in this study is 319 data taken from publication of semiannual financial statement of a general bank which is listed on the Indonesia Stock Exchange during 2007-2014.

a. The minimum of Lerner variable is -0.09 , achieved by Bank Himpunan Saudara 1906, the maximum is 0.29 , achieved by Bank Danamon, the average is 0.08 and the standard deviation is 0.05 with the amount of data as much as 319 .

b. The minimum of Nii variable is -0.12 , achieved by Bank Danamon, the maximum is 0.33 , achieved by Bank Victoria International, the average is 0.2 and the standard deviation is 0.4 with the amount of data as much as 319 .

c. The minimum of Zscore variable is -0.48 , achieved by Bank Bumi Arta, the maximum is 3.87, achieved by Bank Central Asia, the average is 1.31 and the standard deviation is 0.53 with the amount of data as much as 319 .

Tabel 2. Descriptive statistics

Source: results of the researcher's processed data (2016).

\begin{tabular}{|c|c|c|c|c|c|}
\hline Variable & $\mathbf{N}$ & Minimum & Maximum & Mean & Std. deviation \\
\hline Zscore & 319 & -0.48 & 3.87 & 1.3105 & 0.53547 \\
\hline Lerner & 319 & -0.09 & 0.29 & 0.0853 & 0.05888 \\
\hline $\mathrm{Nii}$ & 319 & -0.12 & 0.33 & 0.0206 & 0.04089 \\
\hline Valid N (listwise) & 319 & - & - & - & - \\
\hline
\end{tabular}




\subsection{Simultaneous significance test (F-test)}

Then, to test the market power, income diversification together (simultaneously to the bank stability), we use F-test. The steps to do F-test are:

1. Formulating the hypothesis

$H_{0}: \quad b_{1}=b_{2}=0$ means simultaneously market power and income diversification has insignifficant effect to the general bank stability which listed in Indonesia Stock Exchange.

$H_{1}: \quad b_{1} \neq b_{2} \neq 0$ means simultaneously market power and income diversification has signifficant effect on the general bank's stability which is listed on the Indonesian Stock Exchange.

2. Formulating the test criteria (Gusnardi et al., 2016; Dalimunthe et al., 2016)

If $F_{\text {count }}>F_{\text {table }}$, then $\mathrm{H}_{1}$ will be accepted and $\mathrm{H}_{0}$ will be rejected

If $F_{\text {count }} \leq F_{\text {table }}$, then $\mathrm{H}_{0}$ will be accepted and $\mathrm{H}_{1}$ will be rejected.

\section{Data analysis}

The result of F-test can be seen in Table 3.

According to the table, it can be seen that the $F_{\text {count }}$ is 5.659 higher than $F_{\text {table }}$, with significance level 0.004, lower than 0.05 . Because of it, regression model can be used to predict Zscore, in the other words, Lerner variable and Nii have signifficant effect on the Zscore.

\subsection{Partial significance test (T-test)}

T-test is done to find out whether each independent variable, that is Lerner and Nii, affects Zscore partially. T-test is also done to find out whether suggested hypothesis is accepted or rejected, if $t_{\text {count }}<t_{\text {table }}$, then $\mathrm{H}_{1}$ is rejected and $\mathrm{H}_{0}$ is accepted, if $t_{\text {count }}>t_{\text {table }}$, then $\mathrm{H}_{1}$ is accepted and $\mathrm{H}_{0}$ is rejected (Yahya et al., 2017). If the significance level is below 0.05 , then $\mathrm{H}_{1}$ is accepted and $\mathrm{H}_{0}$ is rejected. The effect of both independent variables on Zscore is partially shown in Table 4 .

Tabel 4. T-statistics test

\begin{tabular}{|c|c|c|c|c|c|}
\hline Model & $\begin{array}{l}\text { Sum of } \\
\text { squares }\end{array}$ & df & $\begin{array}{l}\text { Mean } \\
\text { square }\end{array}$ & $\mathbf{F}$ & Sig. \\
\hline Regression & 3.172 & 2 & 1.586 & 5.695 & $0.004^{\mathrm{a}}$ \\
\hline Residual & 88.009 & 316 & 0.279 & - & - \\
\hline Total & 91.181 & 318 & - & - & - \\
\hline
\end{tabular}

Note: a. Dependent variable: Zscore

From the analysis it can be concluded:

a. Lerner to Zscore shows significance $(0.006)<\alpha(0.05)$, and its $t_{\text {count }}$ is 2.777 , where its $t_{\text {count }}(2.777)>t_{\text {table }}(1.65)$, then $\mathrm{H}_{1}$ is accepted and $\mathrm{H}_{0}$ is rejected. Means there is significant effect between Lerner and Zscore.

b. Nii to Zscore shows significance $(0.108)>\alpha(0.05)$, and its $t_{\text {count }}$ is 1.610 , where $t_{\text {count }}(1.610)<t_{\text {table }}(1.65)$, then $\mathrm{H}_{1}$ is rejected and $\mathrm{H}_{0}$ is accepted. Means there is insignificant effect between Nii and Zscore.

Table 3. F-statistic test

Source: results of the researcher's processed data (2016).

\begin{tabular}{|c|c|c|c|c|c|c|c|}
\hline \multirow[t]{2}{*}{ Model } & \multicolumn{2}{|c|}{$\begin{array}{l}\text { Unstandardized } \\
\text { coefficients }\end{array}$} & \multirow{2}{*}{$\begin{array}{c}\begin{array}{c}\text { Standardized } \\
\text { coefficients }\end{array} \\
\text { Beta }\end{array}$} & \multirow[t]{2}{*}{$\mathbf{t}$} & \multirow[t]{2}{*}{ Sig. } & \multicolumn{2}{|c|}{ Collinearity statistics } \\
\hline & B & Std. error & & & & Tolerance & VIF \\
\hline 1 (Constant) & 1.167 & 0.053 & - & 21.971 & 0.000 & - & - \\
\hline Lerner & 1.404 & 0.506 & 0.154 & 2.777 & 0.006 & 0.989 & 1.012 \\
\hline $\mathrm{Nii}$ & 1.172 & 0.728 & 0.089 & 1.610 & 0.108 & 0.989 & 1.012 \\
\hline
\end{tabular}

Notes: a. Predictors: (Constant), Nii, Lerner. b. Dependent variable: Zscore 


\section{DISCUSSION}

The research result concluded that market power measured by Lerner Index has a significant and positive effect on the bank stability measured by Zscore and founded too in the previous research by Ariss (2010), Amidu (2013), Amidu and Wolfe (2013). The amount of bank's market power will be affected to the bank stability. Bank with big market power has high growth level along with high capital ratio. This result shows that bank with more efficient market power has sufficient resources, sufficient scale and economic scope so that it can do low cost production activity along with enjoying high profit margin (Amidu, 2013). This research's result indicates that income diversification has an unsignifficant and positive effect on the bank stability. This result is inconsistent with other research by Lepetit et al. (2008) stated that non-interest income tends to have higher risk comparing to bank traditional income, so that it will decrease the bank stability. The same result is also stated by Sufian and Habibullah (2010). In Indonesia, income diversification and capitalization can increase bank profit. The implementation plan of the ASEAN Economic Community (MEA) and ASEAN banking integration (ABIF) may cause competition in the banking sector in Indonesia is getting tougher (Muljawan et al., 2014). Therefore, Indonesian banks should always improve efficiency to maintain business continuity and product order and services marketed to compete. The main thing one should pay attention is the activity of credit due to lending of rate Indonesian banks is relatively higher than other countries in ASEAN. Based on SWOT analysis and comparison of several indicators with other countries in ASEAN, post-implementation of ABIF banking Indonesia is expected to compete in the Indonesian market with Indonesian banking prerequisites and should always improve capacity and performance, including efficiency aspects.

\section{CONCLUSION AND SUGGESTION}

\section{Conclusion}

Based on the research result and discussion, it can be conculed:

1. Simultaneously, market power and income diversification have a significant effect on the stability of the general bank listed on the Indonesia Stock Exchange.

2. Partially, market power has a significant and positive effect on the stability of general bank listed on the Indonesia Stock Exchange. Income diversification has an insignificant and positive effect on the general bank's stability which is listed on the Indonesia Stock Exchange.

\section{Suggestion}

Based on the conclusion, researchers give some suggestions:

1. To the banking management in Indonesia, from the result it can be seen that the increasing of bank's market power and income diversification can increase bank stability so that banking management in Indonesia can maintain and increase the market power and develop income diversification in order to keep growing and competing in Indonesia banking industry.

2. The role of Financial Services Authority and Bank Indonesia as regulator is really important to oversee and make policies which support the creation of healthy and efficient banking industry.

3. To the academics, this result can become an additional information to increase the wealth of the scientific literature in terms of research about the effect of bank's market power and income diversification on the bank stability. 


\section{REFERENCES}

1. Acharya, V. V., \& Hasan I., S. A. (2002). The effects of focus and diversification on bank risk and return: evidence from individual bank loan portfolios. Discussion Paper No 3252, Centre for Economic Policy Research, March. Retrieved from http://citeseerx.ist. psu.edu/viewdoc/download?doi $=10.1 \cdot 1 \cdot 200.4050 \& r e p=$ rep $1 \&$ typ $\mathrm{e}=\mathrm{pdf}$

2. Alhassan, A. L. (2015). Income diversification and bank efficiency in an emerging market. Managerial Finance, 41(12), 1318-1335. Retrieved from http://www.emeraldinsight.com/doi/full/10.1108/ MF-12-2014-0304? mobileUi=0

3. Amidu, M., (2013). The Effects of the Structure of Banking Market and Funding Strategy on Risk and Return. International Review of Financial Analysis, 28(1), 143-155. http://dx.doi.org/10.1016/j. irfa.2013.03.001

4. Amidu, M., Wolfe, S. (2013). Does Bank Competition and Diversification Lead To Greater Stability? Evidence From Emerging Markets. Review of Development Finance, 3(1), 152-166. Retrieved from http:// www.sciencedirect.com/science/ article/pii/S1879933713000262

5. Baele, L., Jonghe, O. D., \& Vennet, R. V. (2007). Does the stock market value bank diversification? Journal of Banking and Finance, 31, 1999-2023. Retrieved from https:// www.fdic.gov/bank/analytical/ cfr/bank_research_conference/ annual_6th/de_jonghe_o.pdf

6. Brighi, P., \& Venturelli, V. (2014). How do income diversification, firm size and capital ratio affect performance? Evidence for bank holding companies. Applied Financial Economics, 24(21), 13751392. Retrieved from http://www. tandfonline.com/doi/abs/10.1080/ 09603107.2014.925064

7. Chiorazzo, V., Milani, C., \& Salvini. F. (2008). Income diversification and bank performance: evidence from Italian banks. Journal of Financial Services Research, 33, 181-203. Retrieved from http:// hdl.handle.net/10.1007/s10693008-0029-4

8. Crockett, A. (1997). Why Is Financial Stability A Goal of Public Policy? Paper in Maintaining Financial Stability in a Global Economy Symposium, Federal Reserve Bank of Kansas City, Jackson Hole, Wyoming, 1-36. Retrieved from https://www. kansascityfed.org/publicat/sympos/1997/pdf/s97crock.pdf

9. Dalimunthe, D. M. J., Fadli, \& Muda, I. (2016). The application of performance measurement system model using Malcolm Baldrige Model (MBM) to support Civil State Apparatus Law (ASN) number 5 of 2014 in Indonesia. International Journal of Applied Business and Economic Research, 14(11), 7397-7407. Retrieved from https://www.researchgate.net/ publication/312062497_The_application_of_performance_measurement_system_model_using_Malcolm_Baldrige_Model_MBM_to_support_Civil_State Apparatus_Law_ASN_number_5 of_2014_in_Indonesia

10. Dendawijaya, Lukman (2009). Management of Banking, Ghalia Indonesia, Jakarta. Retrieved from https://www.coursehero.com/file/ pu3l24/Dendawijaya-Lukman2005-Manajemen-PerbankanBogor-Ghalia-Indonesia-2-Firmanto-D/

11. Deng, S. E., Elyasani, E., \& Mao, X. C. (2007). Diversification and the cost of debt of bank holding companies. Journal of Banking and Finance, 31(8), 2453-2473. Retrieved from http://www.fox. temple.edu/cms/wp-content/ uploads/2014/06/Diversificationand-the-Cost-of-Debt-of-BankHolding-Companies.pdf

12. Elyasiani, E., \& Wang, Y. (2012). Bank holding company diversification and production efficiency. Applied Financial Economics, 22(17), 1409-1428. Retrieved from https://www.researchgate.net/publication/254235453_Bank_holding_company_diversification_and_ production_efficiency
13. Firdaus, Muhammad (2011). Econometrics: An Applicative Approach, Second Edition, First Printing, Earth Script, Jakarta. Retrieved from https://www. belbuk.com/ekonometrikasuatu-pendekatan-aplikatif-edisi2-p-24838.html

14. Ghozali, Imam (2012) Multivariate Analysis Application With SPSS Program, Publishers Agency Diponegoro University, Semarang. Retrieved from https://teorionline.wordpress.com/2011/03/01/ ghozali-imam-2007-aplikasianalisis-multivariate-denganprogram-spss-cetakan-ke-ivsemarang-badan-penerbit-undip/

15. Gusnardi, Riadi, R. M., \& Muda, I. (2016). Competency mapping and analysis of students competency based on economics subject national examination and its alternative solutions in state high schools at Pekanbaru. International Journal of Economic Research, 3(5), 2133-2148. Retrieved from https://www.researchgate.net/ publication/310490278_Competency_mapping_and_analysis_of_ students_competency_based_on_ economics_subject_national_examination_and_its_alternative solutions_in_state_high_schools_ at_Pekanbaru

16. Hasibuan, Malayu S. P. (2009) Fundamentals of Banking, Eighth Printing, PT. Bumi Aksara, Jakarta.

17. Kachtouli, \& Hamza (2012). Competitive conditions and market power of Islamic and conventional commercial banks. Journal of Islamic Accounting and Business Research, 5(1), 29-46. https://doi.org/10.1108/JIABR-05-2012-0030

18. Khaldun, Khalidazia, I., \& Muda, I. (2014). The Influence of Profitability And Liquidity Ratios on The Growth of Profit of Manufacturing Companies: a Study of Food and Beverages Sector Companies Listed on Indonesia Stock Exchange (Period 2010-2012). International 
Journal of Economics, Commerce and Management, 2(12),

1-17. Retrieved from http:// ijecm.co.uk/wp-content/uploads/2014/12/21215.pdf

19. Laeven, L., \& Levine, R. (2007). Is there a diversification discount in financial conglomerates? Journal of Financial Economics, 85, 331367. Retrieved from https://EconPapers.repec.org/RePEc:eee:jfinec: v:85:y:2007:i:2:p:331-367

20. Lepetit, L., Nys, E., Rous, P., \& Tarazi, A. (2008). The Expansion of Services In European banking: Implications For Loan Pricing and Interest Margins. Journal of Banking and Finance, 32(11), 2325-2335. Retrieved from https:// econpapers.repec.org/article/ eeejbfina/v_3a32_3ay_3a2008_3ai _3a11_3ap_3a2325-2335.htm

21. Lubis, A., Torong, Z. B., \& Muda, I. (2016). The urgency of implementing balanced scorecard system on local government in North Sumatra - Indonesia. International Journal of Applied Business and Economic Research, 14(11), 7575-7590. Retrieved from https://www.researchgate.net/ publication/312063480_The_urgency_of_implementing_balanced_scorecard_system_on_local_government_in_North_Sumatra_-_Indonesia

22. Lubis, A. F., Lubis, T. A., \& Muda, I. (2016). The role of Enterprise Resource Plan (ERP) configuration to the timeliness of the financial statement presentation. International Journal of Applied Business and Economic Research, 14(11), 7591-7608. Retrieved from http://serialsjournals.com/serialjournalmanager/ pdf/1481524509.pdf

23. Lutfi, M., Nazwar, C., \& Muda, I. (2016). Effects of investment opportunity set, company size and real activity manipulation of issuers in Indonesia Stock Exchange on stock price in Indonesia. International Journal of Economic Research, 13(5), 2149-2161. Retrieved from https://www.researchgate.net/ publication/310490383_Effects_ of_investment_opportunity_set company_size_and_real_activ- ity_manipulation_of_issuers_in Indonesia_Stock_Exchange_on_ stock_price_in_Indonesia

24. Mahdaleta, E., Muda, I., \& Gusnardi Muhammad Nasir (2016). Effects of Capital Structure and Profitability on Corporate Value with Company Size as the Moderating Variable of Manufacturing Companies Listed on Indonesia Stock Exchange. Academic Journal of Economic Studies, 2(3), 30-43. Retrieved from https://EconPapers.repec. org/RePEc:khe:scajes:v:2:y:2016:i :3:p:30-43

25. Maksum, A., Hamid, R., \& Muda, I. (2014). The Impact of Treasurer's Experience And Knowledge on The Effectiveness of The Administration and Preparation of The Accountability Reporting System in North Sumatera. Asian Journal of Finance \& Accounting, 6(2), 301318. Retrieved from http://dx.doi. org/10.5296/ajfa.v6i2.6341

26. Muda, I., \& Abykusno, Dharsuky 2015. Impact Of Region Financial Information System (SIKD) Quality, Role Ambiguity And Training on Precision of Financial Statement of Local Government Presentation In North Sumatra. International Journal of Applied Business and Economic Research, 13(6), 4283-4304. Retrieved from http://www.serialsjournals. com/articles.php?volumesno_ id=919\&journals $\mathrm{id}=22$ \&volumes_id $=788$

27. Muda, I., Deni Yuwilia Wardani, Erlina, Azhar Maksum, Ade Fatma, Lubis \& Rina, Bukit (2017). The Influence of Human Resources Competency and The Use of Information Technology on The Quality of Local Government Financial Report with Regional Accounting System as an Intervening. Journal of Theoretical and Applied Information Technology. 95(19), 1432-1451. Retrieved from http://www.jatit.org/volumes/ Vol95No20/23Vol95No20.pdf

28. Muda, I., Dharsuky. A., Siregar, H. S., \& Sadalia, I. (2017). Combined loading and Crossdimensional loadings timeli- ness of presentation of financial statements of local government. IOP Conference Series : Materials Science and Engineering, 180, 1-5. http://dx.doi.org/10.1088/1757899X/180/1/012099

29. Muda, I., Marlon Sihombing, Erni Jumilawati \& Abikusno Dharsuky (2016). Critical Success Factors Downstream Palm Oil Based Small And Medium Enterprises (SME) In Indonesia. International Journal of Economic Research, 13(8), 3531-3538. Retrieved from http://serialsjournals.com/serialjournalmanager/pdf/1499428227. pdf

30. Muda, I., Mutia Ismail \& Marhayanie (2017). Impact Allocation Capital Expenditure on The Improvement of the Local Government Assets in North Sumatra and Effect on Local Revenue Sustainability. International Journal of Economic Perspectives, 11(2), 151-164. Retrieved from http://www.econsociety.org/ijep_contents_11.2.php

31. Muda, I., Dharsuky, A., Sadalia, I., \& Siregar, H. S. (2016). Impact of capital investments and cash dividend policy on Regional Development Bank (BPD) PT. Bank Sumut to the district own source revenue and economic growth. International Journal of Applied Business and Economic Research, 14(11), 7863-7880. Retrieved from https://ifrnd.org/ journal/index.php/jebs/article/ view $/ 478$

32. Muda, I., \& Ahmad Rafiki (2014). Human Resources Development and Performance of Government Provincial Employees: A Study in North Sumatera, Indonesia. Journal of Economics and Behavioral Studies, 6(2). 152-162. Retrieved from http://en.ruc.findplus.cn/ search_list.html?h=search_list\&query=AR:\%22Muda\%2C\%20 Iskandar\%22

33. Muda, I. (2017). The Effect of Supervisory Board CrossMembership and Supervisory Board Members' Expertise to The Disclosure of Supervisory Board's Report: Empirical Evidence From Indonesia. European Research 
Studies Journal, $X X(3 \mathrm{~A}), 702-$

716. Retrieved from https://ideas. repec.org/a/ers/journl/vxxy2017i3ap691-705.html

34. Muljawan, Dadang, Januar Hafidz, Rieska Indah Astuti \& Rini Oktapiani (2014). Determinants of Indonesia's Banking Efficiency and The Impact on the Calculation of Loan Interest Rates. Working Paper. Macroprudential Policy Department, Bank of Indonesia. Retrieved from http://www.bi.go. id/id/publikasi/wp/Documents/ Efisiensi-Perbankan-revisifinal\%20Juni-2-2014.pdf

35. Nurzaimah, Rasdianto \& Muda, I. (2016). The skills and understanding of rural enterprise management of the preparation of financial statements using Financial Accounting Standards (IFRs) financial statement on the Entities without Public Accountability (ETAP) framework on the implementation of village administration law. International Journal of Applied Business and Economic Research, 14(11), 7417-7429. Retrieved from https://www.researchgate.net/ publication/312450454_The_ skills_and_understanding_of_rural_enterprise_management_of_ the_preparation_of_financial_ statements_using_Financial_Accounting_Standards_IFRs_financial_statement_on_the_Entities_Without_Public_Acco

36. Rini, Endang Sulistya \& Yeni Absah (2017). Rational, emotional and spiritual marketing strategies in Shariah banking in Medan, Indonesia. Banks and Bank Systems, 12(2), 68-77. http://dx.doi. org/10.21511/bbs.12(2).2017.07

37. Sanya, S., \& Wolve, S. (2011). Can banks in emerging economies benefit from revenue diversification? Journal of Financial Service Research, 40, 79-101. Retrieved from https://econpapers.repec.org/ article/kapjfsres/v_3a40_3ay_3a20 11_3ai_3a1_3ap_3a79-101.htm
38. Sawada, M. (2013). How does the stock market value bank diversification? Empirical evidence from Japanese bank. PacificBasin Finance Journal, 25, 40-61. Retrieved from http://dx.doi. org/10.1016/j.pacfin.2013.08.001

39. Sianipar, Aryanti Sariartha (2015). Effect of Income Diversification on Bank Performance. Business Tactics Journal, 19(1), 27-35. Retrieved from http://www.tandfonline.com/ doi/abs/10.2753/REE1540496X5003S312

40. Sirojuzilam, Hakim, S., \& Muda, I. (2016). Identification of factors of failure of Barisan Mountains Agropolitan area development in North Sumatra Indonesia. International Journal of Economic Research, 13(5), 2163-2175. Retrieved from http:// serialsjournals.com/serialjournalmanager/pdf/1499428227.pdf

41. Sufian, F., \& Habibullah, M. S. (2010). Assessing the Impact of Financial Crisis on Bank Performance. ASEAN Economic Bulletin, 27(3), 245-262.

Retrieved from https://muse.jhu. edu/article/412771/pdf

42. Sugiyono (2009). Quantitative Research Methods, Qualitative and $R$ \& $D$, Alfabeta, Bandung. Retrieved from http://www.cvalfabeta.com/0223-detail-metode_ penelitian_kuantitatif_kualitatif_dan_r\&d.html

43. Tarmizi, H. B., Daulay, M. \& Muda, I. (2016). The influence of population growth, economic growth and construction cost index on the local revenue of tax on acquisition of land and building after the implementation of law No 28 of 2009. International Journal of Economic Research, 13(5), 22852295. Retrieved from http://www. serialsjournals.com/serialjournalmanager/pdf/1502169196.pdf
44. Tarmizi, H. B., Daulay, M., \& Muda, I. (2017). Impact of The Economic Growth and Acquisition of Land to The Construction Cost Index in North Sumatera. IOP Conference Series: Materials Science and Engineering, 180, 1-6. http://dx.doi.org/10.1088/1757899X/180/1/012004

45. Vennet, V. R. (2002). Cost and profit efficiency of financial conglomerates and universal banks in Europe. Journal of Money, Credit and Banking, 34(1), 254-282. Retrieved from http://muse.jhu. edu/article/20738/pdf

46. Warjiyo, Perry (2006). Stability of Banking System and Development Policy in Indonesia. Bulletin of Monetary Economics and Banking, 8(4), 20-32. Retrieved from http:// library.um.ac.id/free-contents/ index.php/buku/detail/kebijakanmoneter-di-indonesia-oleh-perrywarjiyo-dan-solikin-29284.html

47. Wijaya, Krisna (2010). Analysis of National Banking Policy, PT. ElexMedia Komputindo, Jakarta. Retrieved from http://www.bukukita.com/Ekonomi-dan-Manajemen/Keuangan/80810-AnalisisKebijakan-Perbankan-Nasional. html

48. Yahya, I, Torong, Z. B., \& Muda, I. (2017). Influence Behavior in Legislature Budget Development of Regions in the Province of Aceh and North Sumatra. International Journal of Economic Research, 14(8), 147-159. Retrieved from http://serialsjournals. com/articles.php?volumesno id $=1276 \&$ journals id=41\&volumes_id $=1068$

49. Zhou, K. (2014). The effect of income diversification on bank risk: evidence from China. Emerging Markets Finance and Trade, 50(3), 2001-2013. Retrieved from http://www.tandfonline. com/doi/abs/10.2753/REE1540496X5003S312 